Journal of Animal and Veterinary Advances 11 (1): 13-19, 2012

ISSN: $1680-5593$

(C) Medwell Journals, 2012

\title{
Associations of Melanocortin-4 Receptor $(M C 4 R)$ Gene Single Nucleotide Polymorphisms with Carcass Traits in a Synthetic Broiler Line
}

\author{
Y. Zhou, D.G. Cao, Q.X. Lei, H.X. Han, F.W. Li, G.M. Li and B.H. Huang \\ Poultry Institute of Shandong, Academy of Agricultural Science, Jinan, China
}

\begin{abstract}
The effect of MC4R Single Nucleotide Polymorphisms (SNPs) and the carcass traits in a synthetic broiler line was investigated. A total of 180 chicken samples were genotyped with Single Strand Conformation Polymorphism (PCR-SSCP) and PCR-Restriction Fragment Length Polymorphism (PCR-RFLP). As a result, four SNPs (C85T, G187A, G622C and G923T) were identified and the C85T SNP was found for the first time. C85T and G187A (Locus A) genotypes were significantly associated with live Body Weight (BW), Carcass Weight (CW), Semi-Eviscerated Weight (SEW), Eviscerated Weight (EW) ( $<<0.01$ ), Breast Muscle Weight (BMW), Percentage of Breast Muscle (BMP) and Leg Muscle Weight (LMW) ( $<<0.05)$. The G622C (Locus B) genotypes were associated with BW, CW, SEW and Percentage of Leg Muscle (LMP) $(\mathrm{p}<0.01)$ whereas the G923T (Locus C) genotypes were associated with Carcass Percentage (CP) and Percentage of Breast Muscle (BMP) $(\mathrm{p}<0.05)$. The haplotypes constructed on the four SNPs were associated with BW, CW, EW, BMW ( $<<0.01$ ), CP and LMP $(\mathrm{p}<0.05)$. Significantly dominant effects of diplotypes $\mathrm{H} 3 \mathrm{H} 5$ were observed for traits $\mathrm{BW}, \mathrm{CW}, \mathrm{EW}, \mathrm{BMW}$ and LMP whereas $\mathrm{H} 1 \mathrm{H} 2$ had a negative effect on $\mathrm{BW}, \mathrm{CW}, \mathrm{EW}$ and $\mathrm{BMW}$.
\end{abstract}

Key words: Chicken, $M C 4 R$ gene, SNPs, PCR-SSCP, PCR-RFLP, China

\section{INTRODUCTION}

Melanocortins are known to have a broad array of physiological actions including the regulation of adrenal cortical function (Adrenocorticotropic hormone, CTH), melanocyte pigmentation, thermoregulation, obesity, the cardiovascular system, learning and memory, immunomodulation and parturition (Walker et al., 1980; Gantz et al., 1993b; Kim et al., 2002). Melanocortins mediate their effects through $\mathrm{G}$ protein-coupled receptors by stimulating adenylate cyclase (Mountjoy et al., 1992). Melanocortin receptors have five subtypes corresponding to the orders in which they were cloned. The receptors differ in their tissue distributions as well as physiological functions (Gantz et al., 1993a; Ellacott and Cone, 2006 ). Melanocortin 4 Receptor (MC4R) was found to be involved in mediating a number of neuroendocrine, autonomic processes, food intake and body weight (Vaisse et al., 2000; Hoggard et al., 2004; Sinha et al., 2004).

The human Melanocortin 4 Receptor $(M C 4 R)$ gene is an intronless gene encoding a seven-transmembranespanning protein of 331 amino acids in length, localized on chromosome 18q21.3 (Gantz et al., 1993b) and was later sublocalized to 18q21.32 (Gerken et al., 1994). It is expressed primarily in the brain but its expression is notably absent in the adrenal cortex, melanocytes and placenta (Gantz et al., 1993b). The bovine Melanocortin Receptor 4 (MC4R) was mapped to BTU 24 comparing human, pig and rat homologues showed a 87,85 and $89 \%$ identity on the DNA level, respectively and $>90 \%$ on the protein level (Haegeman et al., 2001). The Chicken Melanocortin Receptor 4 (CMC4R) encodes a 331 amino acid protein sharing $86.4-88.1 \%$ identity with mammalian analogs. Like human $M C 4 R$ gene, CMC4R also contains no introns in its genomic DNA sequence. Reverse transcription-PCR analysis revealed that the CMC4R mRNA is expressed in a wide variety of peripheral tissues including the adrenal, gonads, spleen and adipose tissues as well as in the brain (Takeuchi and Takahashi, 1998). The high homology in nucleotide sequence and amino acid sequences of $M C 4 R$ gene between different species indicated the conservative function of $M C 4 R$ gene and its expression product.

Huszar et al. (1997) revealed that targeted disruption of the MC4R in mice results in an obesity syndrome characterized by hyperphagia, hyperinsulinaemia, hyperglycaemia and increased linear growth with no abnormality of the reproductive or adrenal axes (Huszar et al., 1997). Selective blockage of the MC4R in the brain stimulates food intake in rats and also that MC4R receptor signaling is involved in mediating leptin's inhibitory effect on food consumption (Kask et al., 1998). Marsh et al. (1999) found that MC4R knockout mice do

Corresponding Author: B.H. Huang, Poultry Institute of Shandong Academy of Agricultural Science, Jiaoxiao Rd. \# 1, Jinan, 250023 Shandong Province, China 
not respond to the anorectic effects of the agonist MTII (Marsh et al., 1999). Also, some research results showed that mutations of MC4R were found to be associated with obesity and fat depostion. Vaisse et al. (1998) reported a case of human obesity associated with a frameshift mutation in MC4R. In 2000, they also found a high frequency ( $4 \%$ ) of rare heterozygous MC4R mutations in a large population of morbidly obese patients (Vaisse et al., 2000). A missense mutation (Asp298Asn) in MC4R was associated with fatness, growth and food intake traits in pigs (Kim et al., 2000).

The study is designed to investigate the association between the MC4R polymorphisms and body weight and carcass traits of chickens and to identify useful single nucleotide polymorphisms of MC4R for genetic selection of chicken carcass traits.

\section{MATERIALS AND METHODS}

Animals: About 180 meat-type broilers of Luqin synthetic line developed by Poultry Institute of Shandong Academy of Agricultural Science were studied. Population Luqin was a commercial broiler strain with fast growth speed, crossbred by local chickens of China and an introduced broiler. All birds were hatched on the same day, housed on cages and transferred to the growing pens at the age of 7 weeks. Birds had access to feed (Commercial corn-soybean diets meeting the National Research Council's [NRC] requirements) and water ad libitum. Blood samples were collected from all 180 individuals. Animal care and sampling were approved the local committee of Institution Animal Care and Use for research. The genomic DNA was isolated by the standard phenol/chloroform method.

Phenotypic measurements: At the age of 90 days, live Body Weight (BW) was measured after $12 \mathrm{~h}$ with no access to feed. After slaughter at the same day of age, the carcass traits including Carcass Weight (CW), Eviscerated Weight (EW), Semi-Eviscerated Weight (SEW), Breast Muscle Weight (BMW) and Leg Muscle Weight (LMW) were measured. The CW was measured on the chilled carcass after removal of the feather. Semi-eviscerated weight was measured on the carcass after removal of the trachea, esophagus, gastrointestinal tract, spleen, pancreas and gonad. Eviscerated weight was measured on the semi-eviscerated weight after removal of the head, claws, heart, liver, gizzard, glandular stomach and abdominal fat. The ratios of these traits to $\mathrm{CW}$ were calculated as Eviscerated Percentage (EP), SemiEviscerated Percentage (SEP), Breast Muscle Percentage (BMP) and Leg Muscle Percentage (LMP). The ratio of carcass weight to live body weight was calculated as
Table 1: Forward $(\mathrm{F})$ and Reverse $(\mathrm{R})$ primers for amplification of the chicken $M C 4 R$ gene

\begin{tabular}{llcc}
\hline $\begin{array}{l}\text { Primer } \\
\text { set }\end{array}$ & Forward primer $\left(5^{\prime}-3^{3}\right)$ & $\begin{array}{c}\text { Annealing } \\
\text { temperature } \\
\left({ }^{\circ} \mathrm{C}\right)\end{array}$ & $\begin{array}{c}\text { Product } \\
\text { length } \\
(\mathrm{bp})\end{array}$ \\
\hline 1 & $\begin{array}{l}\text { F: AAGCTTGCGCACATCCAAGT } \\
2\end{array}$ & 54.8 & 232 \\
2 & $\begin{array}{l}\text { R: GCTGCCGAGCAGAAACTAAT } \\
\text { F: CCATAAGATGAATTCACCCAG }\end{array}$ & 55.6 & 210 \\
& $\begin{array}{l}\text { R: TTGCCACAATGACCAAGACG } \\
\text { F: TAGCCAAGAACAAGAACC }\end{array}$ & 50.6 & 610 \\
& R: GGGCAGGAGATGTAGAAA & & \\
\hline
\end{tabular}

Carcass Percentage (CP). All the experiments were complied with the requirements of the directory proposals on the ethical treatment of experimental animals of China.

Genotyping for $M C 4 R$ gene polymorphisms: Three primers were designed to investigate the SNPs in the MC4R gene, according to the Gallus gallus MC4R sequence (GenBank Accession No. : AB012211, Table 1). Primer set 1 (Qiu et al., 2006) was used to amplify the fragment (232bp) of the 5'-Untranslated Region (5'-UTR) of MC4R gene, the primer set 2 (Tao et al., 2008) and primer set 3 were used to amplify the exon of the $M C 4 R$ gene. The PCR reaction was performed in a final volume of $10 \mu \mathrm{L}$ containing $0.8 \mu \mathrm{L}$ of genomic DNA $\left(2.5 \mathrm{ng} \mu \mathrm{L}^{-1}\right)$, $0.3 \mu \mathrm{L}$ of each primer $\left(10 \mathrm{pmol} \mu \mathrm{L}^{-1}\right), 3.6 \mu \mathrm{L} \mathrm{ddH}_{2} \mathrm{O}, 5 \mu \mathrm{L}$ of $2 \times$ MasterMix (Tiangen, Beijing, China). The following PCR cycle condition was used: an initial denaturation at $94^{\circ} \mathrm{C}$ for $5 \mathrm{~min} ; 35 \mathrm{cycles}$ of $94^{\circ} \mathrm{C}$ for $30 \mathrm{sec}, 50.6-55.6^{\circ} \mathrm{C}$ (depends on the primer pair used) for $30 \mathrm{sec}$ and $72^{\circ} \mathrm{C}$ for $60 \mathrm{sec}$ and a final elongation at $72^{\circ} \mathrm{C}$ for $10 \mathrm{~min}$. The PCR products of primer set 1 and 2 were screened by the SSCP method and separated by $12 \%$ polyacrylamide gel electrophoresis.

The amplified fragment of primer set 3 were digested with restriction enzyme Fbrl in a total volume of $15 \mu \mathrm{L}$ reaction buffer containing $8 \mu \mathrm{L}$ PCR product and $5 \mathrm{U}$ of enzyme at $37^{\circ} \mathrm{C}$ overnight.

The digests with the Fbrl enzyme were detected through $1.5 \%$ agarose gel electrophoresis, genotypes were recorded according to the band patterns. PCR products that had polymorphism as revealed by PCRSSCP and PCR-RFLP were further amplified, purified and sequenced by a commercial sequencing company (Invitrogen, Shanghai, China).

Statistical analysis: The data were analyzed by the GLM procedures of SAS (SAS Inst. Inc., Cary NC). The genetic effects were analyzed by mixed procedure according to the following model (Zhou et al., 2010):

$$
\mathrm{Y}=\mu+\mathrm{S}+\mathrm{G}+\mathrm{bX}+\mathrm{e}
$$


Where:

$\mathrm{Y}=$ The dependent variable

$\mu=$ The population mean

$\mathrm{S}=$ Fixed effects of sex

$\mathrm{G}=$ Fixed effects of genotype or haplotype

$\mathrm{X}=$ Carcass weight (covariance)

$\mathrm{b}=$ Coefficient of regression

$\mathrm{e}=$ Random error

Multiple comparisons were performed with the least squares means. Values are considered significant at $\mathrm{p}<0.05$ and are presented as least square means \pm standard error means.

The data for some carcass traits were not normally distributed according to the Shapiro-Wilks test in SAS 8.0 (SAS Institute Inc., Cary, NC). BW, CW, SEW, EW, BMW and LMW were analyzed as the linear model with parameters estimated on the Square root scale.

Haplotype reconstruction: Haplotypes were constructed based on the SNPs identified in all 180 experimental birds using the Phase 2.0 programme (Zhou et al., 2010). The function of this program is to reconstruct haplotypes from the population data. The genetic statuses of the subjects were expressed as the combination of two haplotypes (diplotype configuration). Genetic effects of the diplotypes were performed with the mixed model mentioned above.

\section{RESULTS AND DISCUSSION}

Four MC4R SNPs were detected by the PCR-SSCP and PCR-RFLP methods which produced nine genotypes (Fig. 1 and Table 2). The homozygous genotype for each locus was further confirmed by sequencing. For locus A, the $\mathrm{C} \rightarrow \mathrm{T}$ mutation at position $85 \mathrm{nt}$ and $\mathrm{G} \rightarrow \mathrm{A}$ mutation at position 187 nt (relative to GenBank Accession No. AB012211) were located on the 5'UTR. For locus B, the $\mathrm{G} \rightarrow \mathrm{C}$ mutation at position $622 \mathrm{nt}$ was located on the exon and caused the translating change from amino acid Gln to His. For locus $\mathrm{C}$, the $\mathrm{G} \rightarrow \mathrm{T}$ mutation at position $923 \mathrm{nt}$ was located on the exon and this SNP did not cause amino acid change.

The C85T and G187A of MC4R gene was resulted in three different gel profiles (A1A1, A1A12 and A2A2) (Fig. 1a). The three genotypes (B1B1, B1B2 and B2B2) of $\mathrm{G} 622 \mathrm{C}$ in $M C 4 R$ gene could be well recognized by three different gel profiles (Fig. 1b). And G923T of MC4R were also resulted in three genotypes $(\mathrm{C} 1 \mathrm{C} 1, \mathrm{C} 1 \mathrm{C} 2$ and $\mathrm{C} 2 \mathrm{C} 2)$ (Fig. 1c).

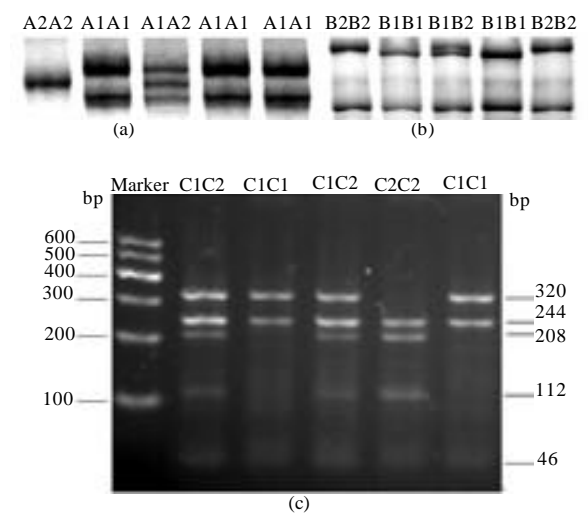

Fig. 1: The genotypes of the C85T, G187A and G923T single nucleotide polymorphisms in the chicken MC4R gene. a) Genotypes of C85T and G187A; b) G622C and c) G923T

Table 2: The GLM analysis of association between the chicken carcass traits and MC4R gene SNPs

\begin{tabular}{|c|c|c|c|}
\hline \multirow[b]{2}{*}{ Traits } & \multicolumn{3}{|l|}{ Locus A } \\
\hline & $\mathrm{A} 1 \mathrm{~A} 1(138)$ & $\mathrm{A} 1 \mathrm{~A} 2(32)$ & $\mathrm{A} 2 \mathrm{~A} 2(10)$ \\
\hline Live body weight (g) & $1760.65 \pm 25.38^{\mathrm{AB}}$ & $1995.74 \pm 52.71^{\mathrm{A}}$ & $1618.40 \pm 94.29^{\mathrm{B}}$ \\
\hline Carcass weight (g) & $1610.74 \pm 24.78^{\mathrm{AB}}$ & $1843.29 \pm 51.47^{\mathrm{A}}$ & $1476.72 \pm 92.07^{\mathrm{B}}$ \\
\hline Semi-eviscerated weight (g) & $1473.33 \pm 24.29^{\mathrm{AB}}$ & $1695.84 \pm 50.44^{\mathrm{A}}$ & $1348.10 \pm 90.24^{\mathrm{B}}$ \\
\hline Eviscerated weight (g) & $1254.04 \pm 21.00^{\mathrm{AB}}$ & $1433.55 \pm 43.61^{\mathrm{A}}$ & $1152.90 \pm 78.02^{\mathrm{B}}$ \\
\hline Breast muscle weight (g) & $187.11 \pm 3.220^{\mathrm{ab}}$ & $201.86 \pm 6.690^{\mathrm{a}}$ & $161.54 \pm 11.97^{b}$ \\
\hline Percentage of breast muscle & $15.01 \pm 0.160^{\mathrm{a}}$ & $14.19 \pm 0.340^{\mathrm{ab}}$ & $13.99 \pm 0.610^{b}$ \\
\hline \multirow[t]{3}{*}{ Leg muscle weight $(\mathrm{g})$} & $128.59 \pm 3.150^{b}$ & $156.47 \pm 6.540^{\mathrm{a}}$ & $123.05 \pm 11.71^{\mathrm{ab}}$ \\
\hline & \multicolumn{3}{|l|}{ Locus B } \\
\hline & $\mathrm{B} 1 \mathrm{~B} 1(100)$ & $\mathrm{B} 1 \mathrm{~B} 2(60)$ & $\mathrm{B} 2 \mathrm{~B} 2(20)$ \\
\hline Live body weight (g) & $1737.11 \pm 30.44^{\mathrm{B}}$ & $1904.84 \pm 39.30^{\mathrm{A}}$ & $1750.80 \pm 68.07^{\mathrm{AB}}$ \\
\hline Carcass weight (g) & $1583.01 \pm 21.12^{\mathrm{B}}$ & $1753.59 \pm 38.33^{\mathrm{A}}$ & $1625.92 \pm 66.40^{\mathrm{AB}}$ \\
\hline Semi-eviscerated weight $(\mathrm{g})$ & $1446.85 \pm 29.05^{\mathrm{B}}$ & $1611.29 \pm 37.50^{\mathrm{A}}$ & $1485.25 \pm 64.96^{\mathrm{AB}}$ \\
\hline \multirow{3}{*}{ Percentage of leg muscle } & $20.08 \pm 0.280^{\mathrm{B}}$ & $21.47 \pm 0.370^{\mathrm{A}}$ & $21.30 \pm 0.640^{\mathrm{AB}}$ \\
\hline & \multicolumn{3}{|l|}{ Locus $\mathrm{C}$} \\
\hline & $\mathrm{C} 1 \mathrm{C} 1(96)$ & $\mathrm{C} 1 \mathrm{C} 2(76)$ & $\mathrm{C} 2 \mathrm{C} 2(8)$ \\
\hline Percentage of carcass & $91.99 \pm 0.29^{a}$ & $91.00 \pm 0.33^{\mathrm{ab}}$ & $90.52 \pm 1.03^{b}$ \\
\hline Percentage of breast muscle & $14.46 \pm 0.19^{b}$ & $15.22 \pm 0.22^{\mathrm{a}}$ & $15.03 \pm 0.69^{a b}$ \\
\hline
\end{tabular}


Table 3: Haplotypes inferred based on the 4 single nucleotide polymorphisms in the chicken $M C 4 R$ gene

\begin{tabular}{lccccc}
\hline \multicolumn{7}{l}{ Haplotypes } & $\mathrm{T}+85 \mathrm{C}$ & $\mathrm{A}+187 \mathrm{G}$ & $\mathrm{C}+622 \mathrm{G}$ & $\mathrm{T}+923 \mathrm{G}$ & Frequency (\%) \\
\hline H1 & $\mathrm{C}$ & $\mathrm{G}$ & $\mathrm{G}$ & $\mathrm{G}$ & 38.25 \\
$\mathrm{H} 2$ & $\mathrm{C}$ & $\mathrm{G}$ & $\mathrm{G}$ & $\mathrm{T}$ & 22.22 \\
H3 & $\mathrm{C}$ & $\mathrm{G}$ & $\mathrm{C}$ & $\mathrm{G}$ & 22.96 \\
H4 & $\mathrm{C}$ & $\mathrm{G}$ & $\mathrm{C}$ & $\mathrm{T}$ & 2.13 \\
H5 & $\mathrm{T}$ & $\mathrm{A}$ & $\mathrm{G}$ & $\mathrm{G}$ & 10.54 \\
H6 & $\mathrm{T}$ & $\mathrm{A}$ & $\mathrm{G}$ & $\mathrm{T}$ & 1.21 \\
H7 & $\mathrm{T}$ & $\mathrm{A}$ & $\mathrm{C}$ & $\mathrm{G}$ & 2.69 \\
\hline
\end{tabular}

Table 4: Diplotypes inferred based on the 7 chicken $M C 4 R$ gene haplotypes in experimental populations

\begin{tabular}{lc}
\hline Diplotypes & Frequency $(\%)$ \\
\hline H1H1 & 14.45 \\
H1H2 & 22.22 \\
H1H3 & 11.11 \\
H1H5 & 10.00 \\
H2H2 & 4.44 \\
H2H3 & 14.45 \\
H2H5 & 1.11 \\
H3H3 & 7.78 \\
H3H4 & 2.22 \\
H3H5 & 6.67 \\
H5H5 & 1.11 \\
H5H6 & 2.22 \\
H5H7 & 1.11 \\
H7H7 & 1.11 \\
\hline
\end{tabular}

The analysis of association between genotypes of the $M C 4 R$ gene and 11 carcass traits (BW, CW, SEW, EW, BMW, LMW, CP, SEP, EP, BMP and LMP) were shown in Table 2. In locus $\mathrm{A}$, genotypes have great significantly effect on BW, CW, SEW, EW, BMW, BMP and LMW but no association was observed for the other 4 carcass traits. In particular, the chickens harboring genotype A1 A2 had significantly higher BW, CW, SEW and EW $(p<0.01)$, BMW and LMW $(p<0.05)$ than those of A 2 A 2 chickens or A1 A1 chickens. In locus B, genotypes had significantly effect on BW, CW, SEW and LMP. All the four traits values of B1B2 chickens were significantly higher than B1B1 chickens $(\mathrm{p}<0.01)$. In locus $C$, genotypes had great significantly effect on $\mathrm{CP}$ and BMP. The $\mathrm{C} 1 \mathrm{C} 1$ chickens had higher $\mathrm{CP}$ than $\mathrm{C} 2 \mathrm{C} 2$ chickens $(\mathrm{p}<0.05)$. The $\mathrm{BMP}$ of $\mathrm{C} 1 \mathrm{C} 2$ chickens was higher than $\mathrm{C} 1 \mathrm{C} 1$ chickens $(\mathrm{p}<0.05)$ but no difference with $\mathrm{C} 2 \mathrm{C} 2$ chickens.

All haplotypes that were reconstructed from the 4 SNPs identified in all 180 experimental birds were shown in Table 3. Seven haplotypes with the minor frequencies above $1.21 \%$ were identified. Three main haplotypesCGGG, CGGT and CGCG accounted for $83.43 \%$ of the observations. Fourteen diplotypes were obtained from these 7 haplotypes with all the frequency $>1 \%$. To make the results more accurate, the diplotypes with the frequency $<2 \%$ were removed when the associations between the diplotypes and the carcass traits were analyzed (Table 4).
The mixed model analysis indicated that there was significant association between diplotypes and carcass traits (Table 5). Diplotypes were associated with BW, CW, CP, EW, BMW and LMP. Significantly dominant effects of diplotypes $\mathrm{H} 3 \mathrm{H} 5$ were observed for traits $\mathrm{BW}, \mathrm{CW}$, EW, BMW and LMP whereas $\mathrm{H} 1 \mathrm{H} 2$ had a negative effect on BW, CW, EW and BMW.

Pharmacological and genetic studies have provided compelling evidence that $\mathrm{MC} 4 \mathrm{R}$ is an important regulator of food intake, body weight and energy homeostasis (Yeo et al., 2000; Tao and Segaloff, 2003). Gu et al. (1999) identified three allelic variants including two novel ones, Thr112Met and Ile137Thr. One of the novel variants, Ile137Thr, identified in an extremely obese proband (BMI 57) was found to be severely impaired in ligand binding and signaling, raising the possibility that it may contribute to development of obesity ( $\mathrm{Gu}$ et al., 1999). Tao and Segaloff (2003) studied the functional characterization of 11 melanocortin-4 receptor mutations (S58C, N62S, Y157S, C271Y, P78L, G98R, D37V, P48S, V50M, I170V and N274S) associated with childhood obesity and propose a classification scheme for mutant MC4Rs based upon their properties. Tan et al. (2009) sequenced the $M C 4 R$ gene in 2000 subjects with severe early-onset obesity and detected seven different nonsense and 19 non-synonymous mutations in a total of 94 probands. Functional characterization research showed that 11 novel obesity were associated missense mutations. Kim et al. (2000) identified a missense mutation (Asp298Asn) in a region highly conserved among Melanocortin Receptor (MCR) genes of pig MC4R. Analyses of growth and performance test records showed significant associations of MC4R genotypes with backfat and growth rate in a number of lines as well as feed intake overall (Kim et al., 2000). At present, $>10$ SNPs were reported in chicken according to NCBI SNP Bank (http:/www.ncbi.nlm.nih.gov/snp) and other research reports (Qiu et al., 2006; Wang et al., 2009).

In the current study, researcher screened the MC4R SNPs in a synthetic broiler line by PCR-SSCP and PCRRFLP methods. As a result, four SNPs (C85T, G187A, G622C and G923T) were identified, three of them (G187A, G622C and G923T) have been reported previously by others (Qiu et al., 2006; Tao et al., 2008) and the C85T mutation was found for the first time.

The result of the association analysis were in agreement with the data reported by other researchers on chicken and pig MC4R genes (Kim et al., 2000; Qiu et al., 2006; Tao et al., 2008; Wang et al., 2009). The finding of a phenotype associated with heterozygous mutations in the MC4R is consistent with the murine data. This 
Table 5: Associations between diplotypes and the chicken carcass traits ${ }^{1-4}$

\begin{tabular}{|c|c|c|c|c|c|c|}
\hline \multirow[b]{2}{*}{ Diplotypes } & \multicolumn{6}{|l|}{ Traits } \\
\hline & $\begin{array}{l}\text { Live body } \\
\text { weight }(\mathrm{g})^{\text {** }}\end{array}$ & $\begin{array}{c}\text { Carcass } \\
\text { weight }(\mathrm{g})^{* * *}\end{array}$ & $\begin{array}{c}\text { Percentage of } \\
\text { carcass* }\end{array}$ & $\begin{array}{l}\text { Eviscerated } \\
\text { weight }(\mathrm{g})^{\text {*** }}\end{array}$ & $\begin{array}{l}\text { Breast muscle } \\
\text { weight }(\mathrm{g})^{\text {*** }}\end{array}$ & $\begin{array}{l}\text { Percentage of } \\
\text { leg muscle }\end{array}$ \\
\hline H1H1 & $1720.51 \pm 51.720$ & $1562.52 \pm 50.840$ & $90.60 \pm 0.56$ & $1215.09 \pm 43.840$ & $185.59 \pm 7.180$ & $19.72 \pm 0.52$ \\
\hline $\mathrm{H} 1 \mathrm{H} 2$ & $1653.65 \pm 41.690^{2}$ & $1505.46 \pm 40.990$ & $90.94 \pm 0.45$ & $1180.55 \pm 35.340$ & $180.64 \pm 5.790$ & $19.99 \pm 0.42$ \\
\hline $\mathrm{H} 1 \mathrm{H} 3$ & $1928.40 \pm 58.960$ & $1789.87 \pm 57.970$ & $92.89 \pm 0.64$ & $1417.41 \pm 49.980$ & $200.67 \pm 8.180$ & $20.16 \pm 0.60$ \\
\hline H1H5 & $1756.50 \pm 62.150$ & $1615.55 \pm 61.100$ & $91.98 \pm 0.67$ & $1267.60 \pm 52.690$ & $186.67 \pm 8.630$ & $19.93 \pm 0.63$ \\
\hline $\mathrm{H} 2 \mathrm{H} 2$ & $2003.00 \pm 93.230$ & $1818.77 \pm 91.660$ & $90.52 \pm 1.01$ & $1434.25 \pm 79.040$ & $213.29 \pm 12.94$ & $21.50 \pm 0.95$ \\
\hline $\mathrm{H} 2 \mathrm{H} 3$ & $1759.78 \pm 51.710$ & $1599.82 \pm 50.840$ & $90.68 \pm 0.56$ & $1231.88 \pm 43.840$ & $185.09 \pm 7.180$ & $21.57 \pm 0.52$ \\
\hline $\mathrm{H} 3 \mathrm{H} 3$ & $1780.28 \pm 70.470$ & $1656.85 \pm 69.280$ & $93.04 \pm 0.76$ & $1236.22 \pm 59.740$ & $173.45 \pm 9.780$ & $21.49 \pm 0.72$ \\
\hline $\mathrm{H} 3 \mathrm{H} 4$ & $1705.00 \pm 131.85$ & $1574.78 \pm 129.62$ & $92.29 \pm 1.43$ & $1271.40 \pm 111.78$ & $202.51 \pm 18.31$ & $17.60 \pm 1.34$ \\
\hline $\mathrm{H} 3 \mathrm{H} 5$ & $2270.67 \pm 79.120^{1}$ & $2108.70 \pm 74.840$ & $92.82 \pm 0.82$ & $1617.10 \pm 64.530$ & $218.37 \pm 10.57$ & $23.45 \pm 0.77$ \\
\hline H5H6 & $1659.00 \pm 131.85$ & $1527.00 \pm 129.62$ & $91.99 \pm 1.43$ & $1168.40 \pm 111.78$ & $186.53 \pm 18.31$ & $19.69 \pm 1.34$ \\
\hline
\end{tabular}

receptor gene may represent a tightly regulated control point in the homeostatic control of body weight which is sensitive to quantitative variation in MC4R expression (Yeo et al., 2000). Most of the affected patients with MC4R mutation reported thus far have been heterozygous and these obese subjects show no evidence of impaired adrenal or reproductive function. Its worth noting that C85T and G187A polymorphic loci detected from 5'-UTR of MC4R in this study showed significant effect on live body weight and other 6 carcass traits (carcass weight, semi-eviscerated weight, eviscerated weight, breast muscle weight, percentage of breast muscle, leg muscle weight).

The important function of 5'-UTR was to regulate the selective expression of genes. According to the results and the data from human and murine, resaerchers thought that the $\mathrm{C} \rightarrow \mathrm{T}$ and $\mathrm{G} \rightarrow \mathrm{A}$ mutations in 5 '-UTR might cause a significant change of the MC4R expression leading to changes in body weight and carcass traits. The results also showed that chickens with heterozygous mutations had higher body weight value and carcass trait values than chickens with the other two genotypes which is consistent with the murine and human data.

As a traditional approach for studying both trait association (marker vs. trait) and linkage disequilibrium (marker vs. marker), single-marker analysis has created many problems such as noisy, unsatisfied and obscured important localization information (Daly et al., 2001). Haplotype or haplotype block reconstruction was more useful than marker-by-marker analysis and provided a practical solution to resolve these problems (Daly et al., 2001; Zhang et al., 2002). In this study, the H3H5 and $\mathrm{H} 3 \mathrm{H} 3$ diplotypes presented higher $\mathrm{BW}, \mathrm{CW}, \mathrm{CP}, \mathrm{EW}$, BMW and LMP than all the other haplotype combinations, respectively. While the $\mathrm{H} 1 \mathrm{H} 2, \mathrm{H} 2 \mathrm{H} 2$ and $\mathrm{H} 3 \mathrm{H} 4$ diplotype were shown to produce less meat than the other haplotype combinations. The data also showed that haplotypes had not significantly effect on SEW, LMW and BMP ( $>0.05)$ while genotypes of four SNPs were found have great significantly effect on them $(\mathrm{p}<0.05)$, respectively. About BW, CW, CP, EW, BMW and LMP both the haplotypes and the genotypes of four SNPs had great significantly effect on them. Therefore, the associations of haplotypes with phenotypic traits were more accurate than those of single SNP. Haplotype diversity is preferred over one SNP and the method of SNP selection based on maximizing haplotype diversity is preferred (Huang et al., 2003; Zhang et al., 2004, 2005).

\section{CONCLUSION}

In this study, two SNPs (C85T and G187A) in 5'UTR and two SNPs (G622C and G923T) in exon were identified, three of them (G187A, G622C and G923T) have been reported previously by others and the C85T mutation was found for the first time. Each of the four SNPs was significantly associated with more than two carcass traits in chickens. The results implied that the $M C 4 R$ gene may have a major effect on body weight and carcass traits in chickens. The $M C 4 R$ gene can be a useful marker for molecular marker-assisted selection of carcass traits in chickens.

Further definitions of the effect of MC4R variants on chicken carcass traits are still needed in particular confirmation of their inheritance and the associations between MC4R SNPs and carcass traits in other populations before use of the SNP testing for markerassisted selections in poultry breeding.

\section{ACKNOWLEDGEMENTS}

This study was financially supported by the National High Technology Research and Development Program of China (2008AA101001), Promotive research fund for young and middle-aged scientisits of Shandong Province (BS2009NY012), Major Agricultural Stock Breeding Project of Shandong Province (20101z014). 


\section{REFERENCES}

Daly, M.J., J.D. Rioux, S.F. Schaffner, T.J. Hudson and ES. Lander, 2001. High-resolution haplotype structure in the human genome. Nat. Genet., 29: 229-232.

Ellacott, K.L.J. and R.D. Cone, 2006. The role of the central melanocortin system in the regulation of food intake and energy homeostasis: Lessons from mouse models. Philosophical Trans. Royal Soc. Biol. Sci., 361: 1265-1274.

Gantz, I., H. Miwa, Y. Konda, Y. Shimoto and T. Tashiro et al., 1993a. Molecular cloning, expression and gene localization of a fourth melanocortin receptor. J. Biol. Chem., 268: 15174-15179.

Gantz, I., Y. Konda, T. Tashiro, Y. Shimoto and H. Miwa et al., 1993b. Molecular cloning of a novel melanocortin receptor. J. Biol. Chem., 268: 8246-8250.

Gerken, S., K. Fish, D. Uyar, M.H. Polymeropoulos and P. Bradley et al., 1994. Integration of 28 STSs into the physical map of human chromosome 18. Genomics, 24: 612-613.

Gu, W., Z. Tu, P.W. Kleyn, A. Kissebah and L. Duprat et al., 1999. Identification and functional analysis of novel human melanocortin-4 receptor variants. Diabetes, 48: 3635-3639.

Haegeman, A., F. Coopman, K. Jacobs, M. Mattheeuws, A. van Zeveren and L. Peelman, 2001. Bovine melanocortin receptor 4: cDNA sequence, polymorphisms and mapping. Anim. Genet., 32: 189-192.

Hoggard, N., L. Hunter, J.S. Duncan and D.V. Rayner, 2004. Regulation of adipose tissue leptin secretion by alpha-melanocyte -stimulating hormone and agouti- related protein: Further evidence of an interaction between leptin and the melanocortin signalling system. J. Mol. Endocrinol., 32: 145-153.

Huang, Q., Y.X. Fu and E. Boerwinkle, 2003. Comparison of strategies for selecting single nucleotide polymorphisms for case/control association studies. Hum. Genet., 113: 253-257.

Huszar, D., C.A. Lynch, V. Fairchild-Huntress, J.H. Dunmore and Q. Fang et al., 1997. Targeted disruption of the melanocortin- 4 receptor results in obesity in mice. Cell, 88: 131-141.

Kask, A., L. Rago, J.E.S. Wikberg and H.B. Schioth, 1998. Evidence for involvement of the melanocortin $\mathrm{MC}_{4}$ receptor in the effect of leptin on food intake and body weight. Eur. J. Pharmacol., 360: 15-19.

Kim, C.S., S.H. Lee, R.Y. Kim, B.J. Kim and S.Z. Li et al., 2002. Identification of domains directing specificity of coupling to g-proteins for the Melanocortin MC3 and MC4 receptors. J. Biol. Chem., 277: 31310-31317.
Kim, K.S., N. Larsen, T. Short, G. Plastow and M.F. Rothschild, 2000. A missense variant of the porcine melanocortin-4 receptor (MC4R) gene is associated with fatness, growth and feed intake traits. Mammalian Genome, 11: 131-135.

Marsh, D.J., G. Hollopeter, D. Huszar, R. Laufer and K.A. Yagaloff et al., 1999. Response of melanocortin4 receptor-deficient mice to anorectic and orexigenic peptides. Nature Genet., 21: 119-122.

Mountjoy, K.G., L.S. Robbins, M.T. Mortrud and R.D. Cone, 1992. The cloning of a family of genes that encode the melanocortin receptors. Science, 257: 1248-1251.

Qiu, X., N. Li, X. Deng, X. Zhao, Q. Meng and X. Wang, 2006. The single nucleotide polymorphisms of chicken melanocortin-4 receptor (MC4R) gene and their association analysis with carcass traits. Sci. China Ser. C Life Sci., 49: 560-566.

Sinha, P.S., H.B. Schioth and J.B. Tatro, 2004. Roles of the melanocortin 4 receptorin antipyretic and hyperthermic actions of centrally administered alpha-MSH. Brain Res., 1001: 150-158.

Takeuchi, S. and S. Takahashi, 1998. Melanocortin receptor genes in the chicken--tissue distributions. General Comp. Endocrinol., 112: 220-231.

Tan, K., I.D. Pogozheva, G.S.H. Yeo, D. Hadaschik and J.M. Keogh et al., 2009. Functional characterization and structural modeling of obesity associated mutations in the melanocortin 4 receptor. Endocrinology, 150: 114-125.

Tao, Y., G. Li, J. Wang, Y. Hu, G. Zhang and K. Cheng, 2008. SNP of MC4R gene and its association with growth performance in jinghai yellow chicken. China Poultry, 30: 21-23.

Tao, Y.X. and D.L. Segaloff, 2003. Functional characterization of melanocortin-4 receptor mutations associated with childhood obesity. Endocrinology, 144: 4544-4551.

Vaisse, C., K. Clement, B. Guy-Grand and P. Froguel, 1998. A frame shift mutation in human MC4R is associated with a dominant form of obesity. Nature Genet, 20: 113-114.

Vaisse, C., K. Clement, E. Durand, S. Hercberg, B. Guy-Grand and P. Froguel, 2000. Melanocortin-4 receptor mutations are a frequent and heterogeneous cause of morbid obesity. J. Clin. Investigation, 106: 253-262.

Walker, J.M., H. Akil and S.J. Watson, 1980. Evidence for homologous actions of pro-opiocortin products. Science, 210: 1247-1249. 
Wang, Y., Y. Su, X.S. Jiang, Y.P. Liu and X.C. Li et al., 2009. Study on association of single nucleotide polymorphism of MC3R and MC4R genes with carcass and meat quality teaits in chicken. Japan Poultry Sci., 46: 180-187.

Yeo, G.S., I.S. Farooqi, B.G. Challis, R.S. Jackson and S. O'Rahilly, 2000. The role of melanocortin signalling in the control of body weight: Evidence from human and murine genetic models. Q. J. Med., 93: 7-14.

Zhang, K., P. Calabrese, M. Nordborg and F. Sun, 2002. Haplotype block structure and its applications to association studies: Power and study designs. Am. J. Human Genet., 71: 1386-1394.
Zhang, K., Z. Qin, T. Chen, J.S. Liu, M.S. Waterman and F. Sun, 2005. HapBlock: Haplotype block partitioning and tag SNP selection software using a set of dynamic programming algorithms. Bioinformatics, 21: 131-134.

Zhang, W., A. Collins and N.E. Morton, 2004. Does haplotype diversity predict power for association mapping of disease susceptibility? Hum. Genet., 115: 157-164.

Zhou, Y., Y. Liu, X. Jiang, H. Du, X. Li and Q. Zhu, 2010. Polymorphism of chicken myocyte-specific enhancerbinding factor $2 \mathrm{~A}$ gene and its association with chicken carcass traits. Mol. Biol. Rep., 371: 587-594. 